\title{
Improvements in Quality and Antioxidant Capacity of Guava (Psidium Guajava L.) Exposed To UV-C Irradiation
}

\author{
Zuliana Razali ${ }^{1}$, Dominic Soloman George ${ }^{2}$, and Nur Alyani Nazirah Ibrahim ${ }^{2}$
}

\begin{abstract}
The effects of UV-C irradiation on fruit quality and antioxidant capacity of guava fruits were investigated. Mature ripe, freshly harvested guava fruits were treated with UV-C for 30 minutes and 60 minutes, then stored at ambient temperature for 12 days. Attributes of quality including firmness, total soluble solids, titratable acidity and microbial count were monitored periodically throughout storage. Application of UV-C managed to retain most of the quality attributes for a longer period compared to control. Where antioxidant capacity was concerned, both UV30 and UV60 resulted in increased measurements of ascorbic acid, total phenolic content, TAC and DPPH activity.. This study supports the UV-C as an effective and safe technique to improve quality of fruits.
\end{abstract}

Keywords-Quality, Antioxidant capacity, UV-C irradiation, Guava .

\section{INTRODUCTION}

$\mathrm{G}^{\mathrm{u}}$ UAVA (Psidium guajava L.), a tropical fruit from the family Myrtacae is cultivated in many countries worldwide and is well known for its nutritional values [1]-[3]. This super fruit contains numerous health promoting qualities and is rich in dietary fiber, antioxidants, vitamins A and $\mathrm{C}$ as well as minerals such as potassium, copper and manganese [4]-[7]. In fact, consumption of guava has been reported to lower cholesterol, blood pressure, control diabetes and prevent heart attacks. Rich amounts of antioxidants have been found to neutralize carcinogenic substances and promote the apoptosis of cancer cells providing strong evidence that Guava could potentially prevent cancer [7],[8]. Despite the nutritional values, guava has a limited shelf life. Being climacteric in nature, the fruit synthesizes high amounts of ethylene when ripe and softens readily at ambient temperature resulting in the fruit being overripe and mealy by the $6^{\text {th }}$ day [2],[3]. This is characterized by loss of colour, shrinkage, offtaste and development of rot. Although previous studies have shown that low temperature storage could extend the shelf life of guava, most retailing in Malaysia is done under nonrefrigerated conditions. Therefore, there is a crucial need for

Zuliana Razali ${ }^{1}$ is with the Institute of Biological Sciences \& Centre for Research in Biotechnology for Agriculture (CEBAR), Faculty of Science, University of Malaya, 50603 Kuala Lumpur, Malaysia.

Dominic Soloman George and Nur Alyani Nazirah Ibrahim ${ }^{2}$ are with the Institute of Biological Sciences \& Centre for Research in Biotechnology for Agriculture (CEBAR), Faculty of Science, University of Malaya, 50603 Kuala Lumpur, Malaysia. ambient-temperature methods that could extend shelf life and maintain the postharvest quality of guava for better marketability. The use of UV-C irradiation as a disinfectant is well established for water treatment as well as surface decontamination. The application of this method on food, while limited, has been shown to prolong shelf life on some fresh produce [9]-[11]. The non-destructive nature and relatively low cost of this technology make UV-C irradiation a highly desirable method to mitigate the limited shelf life of guava. This must also be accompanied by the assurance that the quality and the nutritional value of the fruit are not compromised. Keeping all this in view, this study undertakes a more holistic approach in investigating the effects of UV-C irradiation on the shelf life and overall quality of Guava stored under ambient temperature.

\section{MAterials And Methods}

\section{A. Plant Material}

Mature and green Lohan guavas were harvested from an orchard in Batu Pahat, Johor and immediately transported to the laboratory. Fruits were then sorted to remove misshaped, defected and infected fruits. They were selected based on their uniform sizes and were free from defects. The fruits were rinsed under running tap water and air-dried.

\section{B. UV-C Treatment}

Whole fruits were arranged under a fluorescence lamp in the UV-C treatment cabinet (Safemate 1.2 Biological Safety Cabinet Class II, Bio Air, Australia) and exposed to the UV-C light for 30 and 60 minutes $(230 \mathrm{~V}-50 \mathrm{~Hz}, 400 \mathrm{~W})$. The distance between the lamp and the fruits were $35 \mathrm{~cm}$. The UV$\mathrm{C}$ fluorescence lamp has peak emission of $254 \mathrm{~nm}$.

\section{C.Storage}

Control and treated fruits were arranged on a table and covered with a basket under ambient conditions $\left(25 \pm{ }^{\circ} \mathrm{C}\right)$. Experimental parameters were studied at 6,9 and 12 days after treatment.

\section{Physicochemical Analysis (Fruit firmness, Total Soluble Solids and Titratable Acidity)}

Fruit firmness defined as the force required to puncture the fruit, was measured using a hardness tester (Mitutoya HR-200) and expressed as $\mathrm{kg} / \mathrm{cm} 2$.Total soluble solids (TSS) were determined using a digital refractometer (Atago PR-1 digital refractometer, Tokyo, Japan) at $25 \pm 1{ }^{\circ} \mathrm{C}$ according to the 
manufacturer's protocol and results were expressed in standard ${ }^{\circ}$ Brix unit. As for the determination of titratable acidity, sample paste was diluted with $\mathrm{ddH}_{2} \mathrm{O}$ and titrated with standardized $0.1 \mathrm{~N}$ sodium hydroxide to a definite faint pink end point (color should persist for $\geq 15$ s) using phenolphthalein as an indicator. The volume of sodium hydroxide used for titration was converted to grams of citric acid per 100 grams of fruit and the titratable acidity (\%TA) was calculated according to the method of [12].

\section{E. Ascorbic Acid Content}

The ascorbic acid content in samples was determined based on the 2,6-dichlorophenol-indophenol (DCPIP) visual titration method [13]. Ascorbic acid was extracted from 5 grams of sample paste using 3\% metaphosphoric acid. The extract was then filtered with Whatman No. 1 filter paper and the resulting filtrate was titrated with standardized dye solution (2,6dichloroindophenol-indophenol and sodium bicarbonate) to a pink end point (color should persist for atleast $15 \mathrm{~s}$ ). The results obtained were expressed as milligrams of ascorbic acid per 100 grams sample.

\section{F. Preparation of extract for antioxidant analysis}

The extraction method was performed according to [14] with slight modifications. Crude extracts were prepared using $80 \%$ methanol with a sample to methanol ratio of $1: 1$. The mixture was placed in a shaking incubator (Shellab Orbital Shaking Incubator S14, OR, USA) at $250 \mathrm{rpm}$ for $30 \mathrm{~min}$ at room temperature, and then centrifuged at $5000 \mathrm{rpm}$ for 20 minutes at $5{ }^{\circ} \mathrm{C}$ using a Beckman J2-MI refrigerated centrifuge. The supernatant was used for the analysis of antioxidant activity.

\section{G. Total polyphenol content}

Total polyphenol content of the sample extracts were determined using Folin-Ciocalteu assay modified to a microscale [15]. Following extraction, $0.79 \mathrm{ml}$ of ddH2O, 0.01 $\mathrm{ml}$ sample or standard solution of gallic acid and $0.05 \mathrm{ml}$ Follin-Ciocalteu reagent was added into a $1.5 \mathrm{ml}$ eppendorf tube and mixed. After exactly 1 minute, $0.15 \mathrm{ml}$ of sodium carbonate was added to the solution, mixed well and allowed to stand at room temperature $\left(25{ }^{\circ} \mathrm{C}\right)$ for 2 hours. The absorbance of the samples and gallic acid standards were measured at a wavelength of $750 \mathrm{~nm}$ using a Shimadzu MRC UV-200-RS spectrophotometer. A standard curve of gallic acid $(y=0.0056 x, R 2=0.9955)$ was prepared and results were reported as milligrams of gallic acid equivalent (GAE) per 100 grams of fruit extract.

\section{H. DPPH radical scavenging assay}

The DPPH assay is based on the method described by [15]. The radical scavenging activity was calculated accordingly:

$\%$ DPPH inhibition $=\left(\mathrm{A}_{\text {control }}-\mathrm{A}_{\text {sample }} / \mathrm{A}_{\text {control }}\right) \times 100$ Where $A_{\text {control }}$ is absorbance reading of control and $A_{\text {sample }}$ is absorbance reading of the sample.

\section{Total Antioxidant Capacity}

The total antioxidant capacity of the samples was measured via a spectrophotometric method described by [16]. A standard curve of ascorbic acid $\left(y=0.0018 x, R^{2}=0.9981\right)$ was prepared and results were reported as micrograms of ascorbic acid equivalent (AAE) per ml fruit extract.

\section{J. Microbial inactivation analysis}

The 3M Petrifilm plate methods are recognized as AOAC Intl. Official Methods of Analysis (3M Food Safety 2010). Microbial count of samples were determined using Petrifilm plates (3M Center, Minn., U.S.A.) for aerobic bacteria and coliform according to [17] and were calculated as colony forming units. The results were expressed as $\log (\mathrm{CFU} / \mathrm{mL})$.

\section{K. Statistical Analysis}

The data obtained were subjected to statistical analysis using SPSS 19.0 software (SPSS Inc., IBM). In this study, data were represented as mean values \pm standard error (SE) for three batches of triplicates $(n=9)$. The significant differences between mean values of samples were determined by analysis of variance (one way-ANOVA) using Tukey's HSD (Honestly Significant Difference) test at a significance level of $\mathrm{p}<0.05$.

\section{Results AND Discussion}

\section{A. Physicochemical (Firmness, Total soluble solids and Titratable acidity)}

Fruit softening is one of the major changes in the ripening of fruits and is universally accepted as one of the main component of evaluating fruit quality. In this study, a significant decrease in firmness was observed in non-treated guava as early as 3 days during storage. In contrast, firmness of UV-C irradiated fruits remained unchanged for 6 days before a decrease was observed thereafter (Table 1). Softening of fruits is a result of cumulative action by cell wall hydrolyzing enzymes on cell wall constituents such as pectin and starch. By the $9^{\text {th }}$ day, control fruits recorded a $59.2 \%$ loss in firmness as opposed to 17 and $20 \%$ loss in firmness for UV30 and UV60 treated fruits on the same day. Retention of fruit firmness in treated fruits could be attributed to the reduction of cell wall activity by UV-C as reported in previous studies [18],[19]. Similar results have been observed in peach [10], pepper [20] and tomatoes [21]. Reduction in the utilization of sugar and the conversion of starch into sugar results in the accumulation of sugars in ripening fruits [22],[23]. As shown in Table 1, TSS in control fruits was higher than UV irradiated fruits. This could be due to the inactivation of cell wall enzymes by UV-C which in turn reduces conversion of sugar from starch [18]. A considerable increase in TSS was found in UV irradiated fruits on the $12^{\text {th }}$ day. This coincided with the rapid softening of the fruits indicating breakdown and conversion of starch to sugars. On the other hand, there was no significant difference in titratable acidity among all the fruits throughout storage. Similar to TSS, titratable acidity of irradiated fruits were observed on the $12^{\text {th }}$ day of storage. 
TABLE 1

EFFECTS OF UV-C IRRADIATION ON THE PHYSICOCHEMICAL PROPERTIES OF PSIDIUM GUAJAVA L.

\begin{tabular}{|l|c|c|c|}
\hline & Firmness (kgf) & $\begin{array}{c}\text { Total Soluble } \\
\text { Solids } \\
\left({ }^{\circ} \text { Brix }\right)\end{array}$ & $\begin{array}{c}\text { Titratable } \\
\text { Acidity } \\
(\%)\end{array}$ \\
\hline Day 0 & & & \\
Control & $0.27 \pm 0.01^{\mathrm{a}}$ & $9.1 \pm 0.1^{\mathrm{a}}$ & $0.38 \pm 0.02^{\mathrm{a}}$ \\
UV 30 & $0.26 \pm 0.02^{\mathrm{a}}$ & $9.2 \pm 0.2^{\mathrm{a}}$ & $0.37 \pm 0.02^{\mathrm{a}}$ \\
UV 60 & $0.27 \pm 0.01^{\mathrm{a}}$ & $9.25 \pm 0.25^{\mathrm{a}}$ & $0.37 \pm 0.02^{\mathrm{a}}$ \\
\hline Day 6 & & & \\
Control & $0.22 \pm 0.01^{\mathrm{b}}$ & $10 \pm 0.15^{\mathrm{b}}$ & $0.38 \pm 0.02^{\mathrm{a}}$ \\
UV 30 & $0.24 \pm 0.01^{\mathrm{a}}$ & $9.3 \pm 0.2^{\mathrm{a}}$ & $0.39 \pm 0.02^{\mathrm{a}}$ \\
UV 60 & $0.25 \pm 0.01^{\mathrm{a}}$ & $9.25 \pm 0.15^{\mathrm{a}}$ & $0.4 \pm 0.01^{\mathrm{a}}$ \\
\hline Day 9 & & & \\
Control & $0.11 \pm 0.02^{\mathrm{d}}$ & $10.55 \pm 0.2^{\mathrm{c}}$ & $0.37 \pm 0.01^{\mathrm{a}}$ \\
UV 30 & $0.21 \pm 0.01^{\mathrm{b}}$ & $9.9 \pm 0.15^{\mathrm{b}}$ & $0.36 \pm 0.01^{\mathrm{a}}$ \\
UV 60 & $0.21 \pm 0.01^{\mathrm{b}}$ & $9.9 \pm 0.15^{\mathrm{b}}$ & $0.37 \pm 0.01^{\mathrm{a}}$ \\
\hline Day 12 & & & \\
Control & $*$ & $*$ & $*$ \\
UV 30 & $0.11 \pm 0.02^{\mathrm{d}}$ & $11 \pm 0.2^{\mathrm{c}}$ & $0.26 \pm 0.02^{\mathrm{b}}$ \\
UV 60 & $0.17 \pm 0.01^{\mathrm{c}}$ & $12.2 \pm 0.25^{\mathrm{d}}$ & $0.25 \pm 0.01^{\mathrm{b}}$ \\
\hline
\end{tabular}

Mean values followed by different letters are significantly different $(\mathrm{p}<0.05)$ $(\mathrm{n}=9)$.

* indicates that the experiment was terminated due to spoilage

\section{B. Antioxidant analysis}

The high ascorbic acid content in guava is one of the most striking nutritional qualities of this fruit. Considering the readily degraded nature of ascorbic acids, methods used to treat fruits must preserve ascorbic acids as much as possible. In this study, as shown in Fig. 1, UV-C irradiation resulted in a considerable increase of ascorbic acids until the $9^{\text {th }}$ day of storage, a similar observation to that reported in mangoes [24]. Nevertheless, some studies have reported the adverse effects of UV-C to ascorbic acid where irradiation significantly degraded ascorbic acids [24],[25]. In this study, the decrease in ascorbic acid during the later period of storage could be a result of reversible oxidation into DHA to scavenge free radicals produced by lipid peroxidation of the tissue [24]. UV$\mathrm{C}$ also significantly improved antioxidant content and activity as reflected by the increase in total antioxidant content, total polyphenol content and DPPH (Table 2). The positive effect of UV-C on antioxidants in plants is mainly due the activation of defence mechanism as a respond to UV-C irradiation which is perceived as an abiotic stress [18]. Subsequently, various oxidative stress- related enzymes are synthesized such as guaicol peroxidase and ascorbate peroxidase. Where polyphenols are concerned, UV-C irradiation on strawberries and peppers were found to increase the metabolic activity of phenylalanine ammonia lyase, the enzyme that catalyzes the first step in the polypropanoid biosynthesis pathway. Furthermore UV-C has been shown to inactivate polyohenol oxidase further preventing polyphenol loss [26].

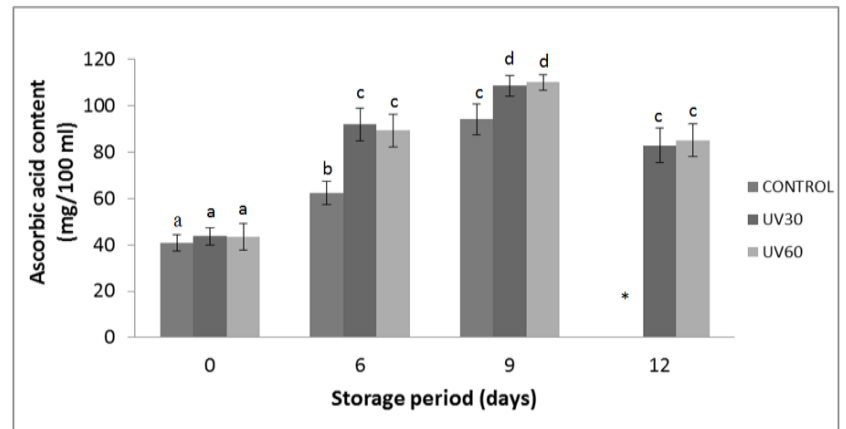

Fig. 1. Effects of UV-C irradiation on the ascorbic acid content of Psidium guajava $\mathrm{L}$. Mean values followed by different letters are significantly different $(\mathrm{p}<0.05)(\mathrm{n}=9)$.

* Shows the experiment terminated due to spoilage

TABLE II

EFFECTS OF UV-C IRRADIATION ON THE ANTIOXIDANT ACTIVITY OF PSIDIUM GUAJAVA L.

\begin{tabular}{|c|c|c|c|}
\hline & $\begin{array}{c}\text { Total } \\
\text { Polyphenol } \\
\text { Content } \\
(\mathrm{mg} \mathrm{GAE} / 100 \mathrm{~g}) \\
\end{array}$ & $\begin{array}{l}\text { DPPH radical } \\
\text { scvenging assay } \\
\text { (\% inhibition) }\end{array}$ & $\begin{array}{c}\text { Total Antioxidant } \\
\text { Capacity } \\
\text { (mg AAE/g) }\end{array}$ \\
\hline $\begin{array}{l}\text { Day 0 } \\
\text { Control } \\
\text { UV } 30 \\
\text { UV } 60 \\
\end{array}$ & $\begin{array}{c}122.82 \pm 2.01^{\mathrm{a}} \\
124.36 \pm 1.98^{\mathrm{ab}} \\
125.84 \pm 2.03^{\mathrm{b}}\end{array}$ & $\begin{array}{l}95.63 \pm 0.35^{\mathrm{a}} \\
96.87 \pm 0.25^{\mathrm{b}} \\
96.78 \pm 0.20^{\mathrm{b}}\end{array}$ & $\begin{array}{l}1240.06 \pm 4.96^{\mathrm{a}} \\
1263.18 \pm 4.03^{\mathrm{b}} \\
1271.72 \pm 3.99^{\mathrm{c}}\end{array}$ \\
\hline $\begin{array}{l}\text { Day 6 } \\
\text { Control } \\
\text { UV } 30 \\
\text { UV } 60 \\
\end{array}$ & $\begin{array}{l}120.78 \pm 1.96^{\mathrm{c}} \\
124.22 \pm 1.93^{\mathrm{ab}} \\
125.66 \pm 2.01^{\mathrm{b}}\end{array}$ & $\begin{array}{l}95.13 \pm 0.22^{\mathrm{ab}} \\
96.77 \pm 0.23^{\mathrm{b}} \\
96.70 \pm 0.18^{\mathrm{b}}\end{array}$ & $\begin{array}{l}1228.05 \pm 4.07^{\mathrm{d}} \\
1260.23 \pm 4.01^{\mathrm{b}} \\
1270.98 \pm 3.98^{\mathrm{c}}\end{array}$ \\
\hline $\begin{array}{l}\text { Day } 9 \\
\text { Control } \\
\text { UV } 30 \\
\text { UV } 60 \\
\end{array}$ & $\begin{array}{c}118.32 \pm 2.04^{\mathrm{d}} \\
123.98 \pm 1.99^{\mathrm{ab}} \\
125.32 \pm 1.98^{\mathrm{b}}\end{array}$ & $\begin{array}{l}94.88 \pm 0.21^{\mathrm{c}} \\
96.44 \pm 0.25^{\mathrm{b}} \\
96.32 \pm 0.19^{\text {bd }}\end{array}$ & $\begin{array}{l}1219.54 \pm 3.88^{\mathrm{e}} \\
1259.97 \pm 4.04^{\mathrm{b}} \\
1270.09 \pm 3.89^{\mathrm{c}}\end{array}$ \\
\hline $\begin{array}{l}\text { Day 12 } \\
\text { Control } \\
\text { UV } 30 \\
\text { UV } 60 \\
\end{array}$ & $\begin{array}{c}* \\
123.86 \pm 2.02^{\mathrm{ab}} \\
125.02 \pm 1.99^{\mathrm{b}}\end{array}$ & $\begin{array}{c}* \\
96.28 \pm 0.21^{\mathrm{bd}} \\
96.10 \pm 0.16^{\mathrm{d}}\end{array}$ & $\begin{array}{c}* \\
1259.13 \pm 3.99^{\mathrm{b}} \\
1268.45 \pm 3.22^{\mathrm{c}} \\
\end{array}$ \\
\hline
\end{tabular}

Mean values followed by different letters are significantly different ( $\mathrm{p}<0.05)(\mathrm{n}=9)$.

* indicates that the experiment was terminated due to spoilage

\section{Microbial analysis}

The aerobic plate count (APC) is the determination of microbial activity towards spoilage of guava fruits while the coliform count is to test the presence of Escherichia coli in the fruit. Spanish, France and Germany legislation established the $7 \log$ CFU/g as the maximum limit for total count of viable bacteria considered safe for human consumption [27],[28] and $7 \log \mathrm{CFU} / \mathrm{ml}$ for fresh cut fruit [29]. After irradiation with UV-C, the APC in UV60 guava showed more considerable decrease in the number of bacteria compared to the UV30 guava and control guava while coliform was completely eliminated in the treated guava (Fig. 2 and 3.) This could be attributed to the direct inhibition of microbial activity by UV$\mathrm{C}$ treatment. UV-C light leads to the formation of crosslink between aromatic amino acids in the DNA strand in the bacteria as well as inducing the formation of pyrimidine dimers. All these DNA modifications cause the disruption in membrane depolarization, abnormal ionic flow of protein as well as introduce the set of mutation in the bacterial DNA [30]-[31]. 


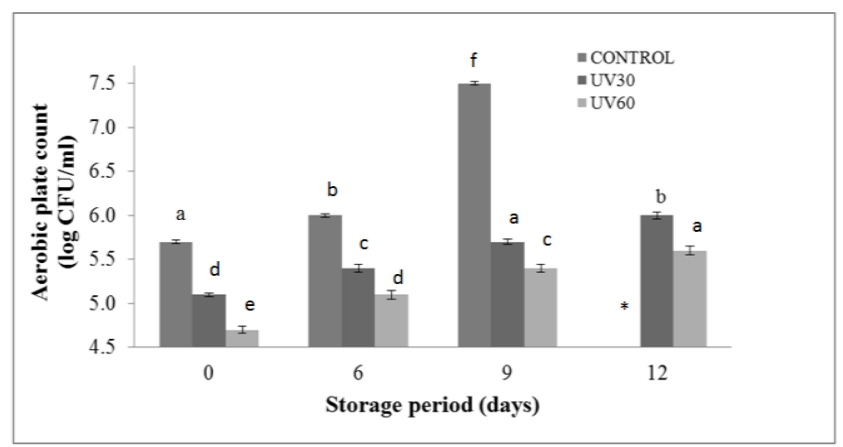

Fig. 2. Effects of UV-C irradiation on the aerobic plate count of Psidium guajava $\mathrm{L}$. Mean values followed by different letters are significantly different $(\mathrm{p}<0.05)(\mathrm{n}=9)$.

* Shows the experiment terminated due to spoilage

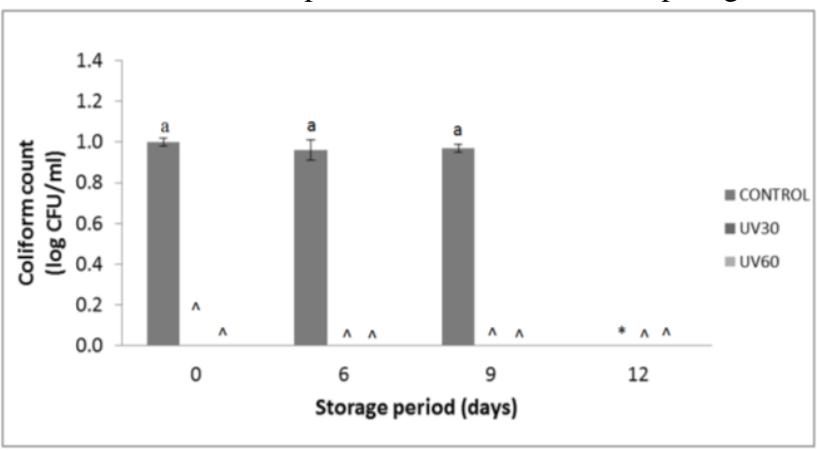

Fig. 3. Effects of UV-C irradiation on the aerobic plate count of

Psidium guajava L. Mean values followed by different letters are significantly different $(\mathrm{p}<0.05)(\mathrm{n}=9)$.

* Shows the experiment terminated due to spoilage

$\wedge$ Coliform not detected

\section{CONCLUSION}

In conclusion treatment of Lohan guava with UV-C irradiation for 30 and 60 minutes retained both physicochemical and nutritional qualities of the fruit at ambient temperature. Hence, UVC30 and UVC60 is a highly desirable method to maintain quality of guava fruits and improve marketability of these fruits.

\section{REFERENCES}

[1] K.B.S. Gill, H. Dhaliwal, and B. Mahajan,"Effect of postharvest treatment on ascorbic acid on quality and shelf life of guava (Psidium guajava L.) CV. Allahabad Safeda" Int. J. Agri. Sci. and Vet. Med. vol. 2(1), pp.130-141,2014.

[2] B. Brown, and R. Wills, "Post-harvest changes in guava fruit of different maturity" Scientia Hort. vol.19(3), pp. 237-243, 1983.

[3] A.B.A. Abu-Goukh and H.A. Bashir, "Changes in pectic enzymes and cellulase activity during guava fruit ripening" Food Chem. vol. 83(2), pp. 213-218, 2003.

[4] B. Joseph and M. Priya, "Review on nutritional, medicinal, and pharmacological properties of guava (Psidium guajava Linn.)" Int. J. of Pharma. and Bio. Sci. vol. 2(1), pp. 53-69, 2011.

[5] M.M.A. Hassimotto, M.I. Genovese and F.M. Lajolo, "Antioxidant activity of dietary fruits, vegetables, and commercial frozen fruit pulps" J. Agri. and Food Chem. vol. 53(8), pp. 2928-2935, 2005.

[6] E. Embaby and M.K. Hassan, "Decay of guava fruit (Psidiumguajava Linn.) quality caused by some mold fungi" Int. J. Agri. Tech. vol. 11(3), pp. 713-730, 2015 .

[7] Q. Wang, et al.,"Positional cloning of a novel potassium channel gene: KVLQT1 mutations cause cardiac arrhythmias" Nature Gen. vol. 12(1), pp. 17-23, 1996.

[8] H.B. Stähelinet al., "Plasma antioxidant vitamins and subsequent cancer mortality in the 12-year follow-up of the prospective Basel Study" Am. J. Epidemeology. vol. 133(8), pp. 766-775, 1991.
[9] F. Artés,P. Gomez, E. Eguayo, V. Escalona and F. Artez- Hernandez, "Sustainable sanitation techniques for keeping quality and safety of fresh-cut plant commodities" Postharvest Biol. and Tech. vol. 51(3), pp. 287-296, 2009.

[10] G.A. Gonzalez-Aguilar, J.A. Villa-Rodriguez, J.F. Ayala-Zarala and E.M. Yahia" "Improvement of the antioxidant status of tropical fruits as a secondary response to some postharvest treatments" Trends in Food Sci. and Tech. vol. 21(10), pp. 475-482, 2010.

[11] J. Severo, et al.,"UV-C radiation modifies the ripening and accumulation of ethylene response factor (ERF) transcripts in tomato fruit" Postharvest Biol. and Tech. vol. 102, pp. 9-16, 2015.

[12] G.D. Sadler, and P.A. Murphy, 'pH and titratable acidity'. In: Nielsen SS, editor. Food analysis. 4th ed. New York: Springer, 2010, pp. 231-3.

[13] S. Ranganna, Chapter 5: ascorbic acid. In: Ranganna S, editor., Manual of analysis of fruit and vegetable products. New Dehli: Tata McGrawHill Publishing Comp., 1977, pp. 94-6.

[14] G. Xu, D. Liu, J. Chen, X. Ye, Y. Maa and J. Shi, "Juice components and antioxidant capacity of citrus varieties cultivated in China" Food Chem. vol. 106, pp. 545-51, 2008.

[15] S. H. Bae and H. J. Suh, "Antioxidant activities of five different mulberry cultivars in Korea" LWT-Food Sci. Technol. vol. 40, pp. 95562, 2007.

[16] P. Prieto, M. Pineda and M. Aguilar, "Spectrophotometric quantitation of antioxidant capacity through the formation of a phosphomolybdenum complex: specific application to the determination of vitamin E" Anal. Biochem. vol. 269, pp. 337-41, 1999.

[17] V. Santhirasegaram, Z. Razali, C.Somasundram C. "Effects of thermal treatment and sonication on quality attributes of Chokanan mango (Mangifera indica L.) juice" Ultrason. Sonochem. vol. 20, pp. 1276-82, 2013.

[18] E.A. Barka, S. Kalantari, J. Makhlouf and J. Arul,“Effects of UV-C irradiation on lipid peroxidation markers during ripening of tomato (Lycopersicon esculentum L.) fruits" Aus. Plant Phys. vol. 27(2), pp. $147-152,2000$.

[19] D.A. Brummell and M.H. Harpster, "Cell wall metabolism in fruit softening and quality and its manipulation in transgenic plants in Plant Cell Walls. Springer, pp. 311-340, 2001.

[20] A.R. Vicente, et al.,"UV-C treatments reduce decay, retain quality and alleviate chilling injury in pepper" Postharvest Biol. and Tech.Vol. 35(1), pp. 69-78, 2005.

[21] R. Maharaj, J. Arul, and P. Nadeau, "Effect of photochemical treatment in the preservation of fresh tomato (Lycopersicon esculentum cv. Capello) by delaying senescence" Postharvest Biol and Tech. vol 15(1) pp. 13-23, 1999.

[22] A. Sharaf and S. El-Saadany, "Biochemical studies on guava fruits during different maturity stages" Food Sci. and Tech. Abs.vol 21, pp. 2544, 1989.

[23] J. Ben and M. Gaweda, "Changes of pectic compounds in Jonathan apples under various storage conditions" ActaPhysiologiaePlanta.Vol 7, pp.45-54, 1985.

[24] M.I. Gil, E. Aguayo, and A.A. Kader, "Quality changes and nutrient retention in fresh-cut versus whole fruits during storage" J. Agri. and Food Chem. vol. 54(12), pp. 4284-4296, 2006.

[25] T. Jiang, M.M. Jahangir, Z. Jiang, X. Lu and T. Ying,"Influence of UV$\mathrm{C}$ treatment on antioxidant capacity, antioxidant enzyme activity and texture of postharvest shiitake (Lentinus edodes) mushrooms during storage" Postharvest Biol. and Tech. vol. 56(3) pp. 209-215, 2010.

[26] G. Oms-Oliu, I. Odriozola-Serrano and O. Martín-Belloso, "The effects of non-thermal technologies on phytochemicals" INTECH Open Access Publisher, 2012.

[27] B.O.E. BoletínOficial del Estado Normas de higienepara la elaboración, distribución y commercio de comidaspreparadas, Madrid, Spain, Real Decreto 3484/2000, pp. 1435-1441, (2001).

[28] G.A. Francis, C. Thomas, and D. O'beirne, "The microbiological safety of minimally processed vegetables" Int. J. Food Sci. and Tech. vol. 34(1), pp. 1-22, 1999.

[29] Public Health Laboratory Services (PHLS), "Guidelines for the microbiological quality of some ready-to-eat foods sampled at the point of sale",Commun Dis Public Health(CDPH), 2000.

[30] R.V. Miller, J.D Mitchell and M. Elasri, "Bacterial responses to ultraviolet light" ASM News-American Society for Microb. vol 65,pp. 535-541, 1999.

[31] B.R. Yaun, S.S Sumner, D. Eifer and J.E Marcy, "Inhibition of pathogens on fresh produce by ultraviolet energy" Int. J. Food Microb. vol. 90(1), pp. 1-8, 2004. 